\title{
Chinese Cultural Diplomacy: instruments in China's strategy for international insertion in the 21st Century
}

DOI: http://dx.doi.org/10.1590/0034-7329201900105

\section{Revista Brasileira de Política Internacional ISSN 1983-3121}

http://www.scielo.br/rbpi

\section{Danielly Silva Ramos Becard ${ }^{1}$ \\ ${ }^{1}$ Universidade de Brasília, Instituto de Relações Internacionais, Brasília, Brazil (daniellyr@yahoo.com) \\ iD ORCID ID: orcid.org/0000-0002-4471-1897}

\section{Paulo Menechelli Filho ${ }^{2}$}

2Universidade de Brasília, Instituto de Relações Internacionais, Brasília, Brazil (prtmfilho@gmail.com)

iD ORCID ID:

orcid.org/0000-0003-1402-265X

\section{Copyright:}

- This is an open-access article distributed under the terms of a Creative Commons Attribution License, which permits unrestricted use, distribution, and reproduction in any medium, provided that the original author and source are credited.

- Este é um artigo publicado em acesso aberto e distribuído sob os termos da Licença de Atribuição Creative Commons, que permite uso irrestrito, distribuição e reprodução em qualquer meio, desde que o autor e a fonte originais sejam creditados.

\section{Introduction}

$\mathrm{I}^{\mathrm{n}}$

\section{Abstract}

This article analyzes instruments of Chinese cultural diplomacy (2003-2018), such as the media, cinema, and the Confucius Institutes, as well as its potential to overcome barriers between states. China's cultural soft power was studied in Confucius Institutes in the U.S.. The conclusion is that China increasingly used cultural diplomacy and turned it into a key instrument in its strategy for international insertion.

Keywords: China; cultural diplomacy; cultural soft power; soft power; Confucius Institutes; China's foreign policy

growing source of social cohesion and creativity, as well as a factor of increasing importance in the strengthening of comprehensive national power (Hu 2007). He added: "We must [...] enhance culture as part of the soft power of our country to better guarantee the people's basic cultural rights and interests." China spared no efforts or resources to strengthen its cultural diplomacy. Among the most evident actions in this process, the internationalization of the Chinese media, the strengthening of Chinese movies, and the spreading of Confucius Institutes (CI) are the most prominent.

Attention to the country's international image has been one of the driving forces of China's foreign policy (Ross and Johnston 2006; Ding 2008; Rabinovitch 2008; Li 2009; Sun 2015; Hartig 2016). Natalia Francesca Riva (2016) states that soft power theory was included in China's national strategy during the $\mathrm{Hu}$ Jintao 
(2003-2013) and the Xi Jinping (2013 to present day) eras. This strategic inclusion has led to the incorporation of soft power and cultural soft power concepts within China's political jargon.

In this context, this article aims to comprehend the relationship between cultural diplomacy and China's strategy for international insertion in the $21^{\text {st }}$ Century. The subject is situated within the field of Foreign Policy Analysis (FPA), according to which culture is a dynamic force and a factor in power struggle (Hudson 2014). Therefore, this article focuses less on culture, and more on the comprehension of who proposed which ideas and how those ideas were put into practice (Wilkening 1999). The use of culture as a political element links directly with the question we seek to answer in this article: how did the Chinese government use cultural diplomacy in its strategy for international insertion in the $21^{\text {st }}$ Century?

The hypothesis is that the Chinese government used cultural diplomacy as a tool to improve its image and others' perception of China. In this sense, cultural diplomacy would thereby raise knowledge about China abroad, which contributes to lowering tensions and creating a more favorable environment for China's international insertion.

In order to test the hypothesis, perspectives and characteristics of China's cultural diplomacy will be analyzed, from its foundation and spanning over actions subsequently undertaken by China. The aim is to understand its practices, its effects, and its potential results, as well as the perception of the environment where these initiatives are received. Thereafter, a case study of the CIs in the U.S. will follow, as this is the country that received and closed the most CIs in the world.

A qualitative and quantitative data analysis was performed in order to comprehend how Chinese soft power is being received. The study on the CIs in the U.S. aimed to conduct detailed descriptions and explanations of one specific case (Johnson et al. 2016; Gerring 2004). The option for the 2003-2018 period is due to the fact that it was during the $\mathrm{Hu}$ Jintao (2003-2013) and the $\mathrm{Xi}$ Jinping (2013-) periods that soft power theory was effectively integrated in China's strategy, which includes the incorporation of expressions such as soft power and cultural soft power into China's political jargon (Riva 2016).

\section{Cultural diplomacy: Chinese visions}

The concept of soft power, created by Joseph Nye in 1990, has had repercussions within both Chinese academia and political discourse. Wang Huning is said to be the one responsible for introducing Nye's writings into China in 1993 (Xiao 2017). According to Wang Huning, soft power is the culture that represents a country's power. He highlights that, among the sources of influences Nye pointed out, culture has a particularly important role for China (Sweet 2017).

Discussions on soft power in China became more sophisticated after academics began to analyze soft power in the context of society and the country's peaceful development, which also can be described as "soft power with Chinese characteristics" (Glaser and Murphy 2009, 11). Zhang (2017) has pointed out that Chinese cultural soft power is radically different from that which 
Joseph Nye defines, in terms of its people-oriented principle, its categories, its main areas and its main problems. One of the differences Zhang (2017) has pointed out relates to the conception of culture intrinsic to the concept of soft power, which is only one of its elements, along with ideals and politics. According to Zhang (2017), apparently Nye's understanding of culture is too strict, because there are supposedly no political values or foreign policies without culture.

Therefore, in China, culture is considered the heart and soul of soft power (Kong 2015), as well as a key resource for state power (Glaser and Murphy 2009). Culture is seen as an important tool for China to increase its soft power, which, through cultural exchanges, hopes to assure the world that it is a civilized, responsible, and reliable nation (Lai 2012). Culture has become such a central focus point that the concept of soft power almost corresponds to cultural power (Cao 2011; Ding 2008). As a result of the augmented value of culture in soft power, the term is gradually being substituted by cultural soft power, whereas culture then would include values of Marxism and socialism as Chinese characteristics, as well as elements of Western culture transformed and adapted to China's cultural system (Kong 2015).

Breslin (2012) has highlighted the importance of promoting history and culture for China's soft power, pointing out that its leaders are aware that the country's political practice might frighten instead of attracting or reassuring foreign observers. China's current political system might be a problem in terms of the projected national image, but there is a belief that the country's history is appealing, and that it is key for China's soft power development (Breslin 2012).

The term cultural soft power is gradually replacing the terms soft power and cultural diplomacy in China. By analyzing the historical use of cultural soft power in other countries, Zhang (2017) underscores the British cultural diplomacy, without mentioning possible similarities or differences between the terms. According to the author, culture has a peculiar role that is irreplaceable in Chinese soft power, because it is not only its heart and soul, but also the framework that accommodates all other aspects of Chinese soft power (Zhang 2017). Furthermore, the term cultural soft power has been frequently used by Xi Jinping: "In order to build a solid foundation for the nation's cultural soft power, China needs to deepen the reform in its cultural system, promote socialist core values and push forward the cultural industry." Xiao $(2017,31)$ has also highlighted the broad use of the term cultural soft power in China, not only on the internet (according to the author, a search on Baidu returned more than 2 million results) but also by the government, which uses the term as a slogan in various contexts.

This leads to the question of whether there are in fact enough differences to pinpoint a Chinese model of cultural diplomacy. On the one hand, it could be argued that China uses instruments of public and cultural diplomacy that are similar to other countries (international media, academic exchange programs, international cultural and art exhibitions, and cultural institutes abroad (Lai 2012)). On the other hand, there are particularities in China's conceptions of soft power and cultural diplomacy, such as: valuing culture in the concept of soft power - which leads to the

${ }^{1}$ Xi 2014 
concept of cultural soft power (Ding 2008; Cao 2011; Glaser and Murphy 2009; Lai 2012; Kong 2015; Riva 2016; Zhang 2017); a more pragmatic rhetoric when it comes to the use of culture as an instrument of power (Hartig 2016); a more central role played by the state in actions of cultural diplomacy - which has more control over the narratives that will be disseminated abroad, and will decide what goes into the country (Shambaugh 2015; Kong 2015; Gil 2015; Zhang 2017); the less evident distinction between public diplomacy and propaganda (Hartig 2016); and the use of cultural diplomacy to ensure cultural security and domestic coherence (Glaser and Murphy 2009; Cao 2011; Kong 2015, Gil 2015; Zhang 2017; Thussu 2018). Perhaps these characteristics are not enough to demonstrate the existence of a Chinese model of cultural diplomacy, but they are enough to demonstrate that there are aspects that demand a deeper, more attentive analysis, which takes into consideration Chinese perspectives on concepts that might hold different meanings from those featured in traditional literature. This is one more reason for the present study, which will investigate the implementation of Chinese cultural diplomacy in the following section.

\section{Chinese cultural diplomacy - global strategic instruments: the media, cinema and Confucius Institutes (Cls)}

In May 2016, Chinese President Xi Jinping stated that, after China had solved its population's problems, which was victim to hunger and foreign violence throughout history, it was time the country stopped being reprimanded by the international community. According to Xi Jinping, a new rhetorical system should be developed in order to facilitate mutual understanding between China and the rest of the world, so as to ultimately promote Chinese soft power (Hu et al. 2018). According to Sun (2015), facing the gap between China's self-image and how it is perceived abroad became the Chinese public diplomacy's most important raison d'etre.

The need to face this difference of perception began to grow during the 1990s, and increased in 2008, following China's successful experience hosting the Beijing Olympics, and its failure to convince the Western world of its plea for Tibet, as well as its way of handling Tibetan human rights (Sun 2015). Therefore, in 2009, the Chinese government decided to accelerate the initiative to internationalize the media, announcing approximately US\$ 6 billion in financing to the sector (Hu and Ji 2012). In 2010, the "Big Four" Beijing media agencies - Xinhua News Agency, China Central Television (CCTV), China Radio International (CRI), and China Daily/Global Times announced new branches in their international sectors (Shambaugh 2013).

The internationalization of Chinese media was intense. Xinhua News Agency currently has 180 international offices - therefore surpassing Associated Press, Reuters and Agence France Press (AFP) - with more than 3 thousand correspondents and locally recruited employees, publications in eight languages (Chinese, English, French, Russian, Spanish, Arabic, Portuguese, and Japanese), as well as audio, video, and photography programming 24 hours a day (Zhou and Wu 2018; Yang 2018); China Central Television (CCTV), which changed its name to China 
Global Television Network (CGTN) in December 2016, broadcasts in 6 channels (2 in English and the others in Arabic, French, and Spanish), in 171 countries, also having signed cooperation agreements with circa 70 foreign media institutions - among them BBC Worldwide -, and news exchange agreements with hundreds of foreign media institutions (Hu et al. 2018); China Radio International (CRI) broadcasts in 65 languages, and is the second largest radio organization in the world, only behind BBC Radio (Yang 2018; Huang 2018); and newspapers China Daily, which, besides publishing on Chinese territory circulate in Hong Kong, the U.S., Canada, Europe, Asia, Africa, and Latin America, and also hold a monthly supplement publication in the Washington Post, Los Angeles Times and Daily Telegraph, from London (Hartig 2018); and the Global Times, which was already launched in English in 2009, was considered "a remarkable innovation" by The Economist (“The Chinese are coming” 2010) and, in 2013, launched a bilingual edition in the U.S., being 16 pages in Chinese and 24 in English. It is printed in Los Angeles, and is the first Chinese newspaper to publish daily news in the United States, in Chinese and in English simultaneously (Mi 2018).

Generally speaking, criticism towards the Chinese media is the same as that made to other instruments of Chinese cultural diplomacy throughout this article: the means of communication are supposedly speakers for the Chinese government, as well as means to disseminate the Chinese Communist Party propaganda (Shambaugh 2013; Hartig 2018). Sun (2015) states that although the expansion and internationalization of the Chinese media was effectuated in order to tell the Chinese story to the world and diminish the difference between its self-image and the world's perception of China, paradoxically, Chinese actions became a new source of anxiety for the West. At the moment, despite strong Chinese investments, its means of communication have still not been able to come close to the great international media outlets. These are still criticized due to their content, which is associated with Chinese state propaganda ( $\mathrm{Si}$ 2014). Nevertheless, in some regions of the global south, especially in Africa (Gagliardone 2013; Yanqiu and Matingwina 2016), these outlets have been partially successful. The persistence of China's strategies to improve its outlets' quality and credibility - with exchange programs between local and international journalists for example (Hartig 2018) -, along with large investments (Thussu 2018), might change the scenario, especially in an environment of growing digital connectivity and technological innovation.

Unlike other sectors analyzed in this article, the Chinese film industry has assets that allow it a more privileged international stance. China has become the country with the largest number of movie theaters in the world (Price Waterhouse Cooper 2017), therefore attracting Hollywood and other global players' attention (Kokas 2018; Thussu 2018). In order to protect this market, China imposed a system of quotas that limits the number of big-budget foreign films to 34 a year (Kokas 2017). A way to bypass this limitation is through international co-production. Co-production between Chinese studios and Hollywood has become increasingly common: between 2002 and 2013, 41 films were co-produced (Thussu 2018). However, in co-production, China ends up having more power on the projects' courses, which includes control of the moment of 
exhibition, demands by Chinese financiers and the recording of scenes in China, with Chinese actors (Kokas 2017).

According to Aynne Kokas (2017), there has been a remarkable increase in Chinese censors' ability to shape co-productions with Hollywood. In "Iron Man 3" (2013), two versions of the movie were produced, one for Asia with pro-China elements (for example, beverages from the Yili brand and acupuncture), which are removed in the North-American version, in order to avoid viewers' estrangement. In the movie “Transformers: Age of Extinction” (2014), produced by Paramount with the help from Jiaflix Enterprises and China Movie Channel (owned by CCTV), the script was tempered in order to respect Chinese censors. In the movie "Pixels" (2015), there were scenes where aliens exploded the Great Wall of China, which were preemptively deleted by Sony (Thussu 2018). For Kokas (2017), Hollywood has learned not to cast Chinese individuals as villains, nor call too much attention to sensitive issues, such as Tibet. Robert Daly, director of the Kissinger Institute on China and the United States at the Wilson Center in Washington DC, also mentioned the fact that "there have been no films in recent years that depict the Chinese Communist Party or mainland Chinese characters in a critical light. [...] Instead, China has saved the world in '2012' and 'The Martian'." 2 Kokas has highlighted that granting control of Hollywood blockbusters to Chinese censors marks a tipping point in Hollywood's relationship with China. She concludes that, if the Chinese market keeps growing, new productions will be increasingly directed to China (Kokas 2017). This content control by China aims both to avoid negative representations of China abroad and to control what is displayed within China. This is related to the dual function of Chinese cultural diplomacy, which is seen as a fundamental strategy to compensate for the cultural hegemony of Western countries, and to counterbalance cultural modernization and westernization within China while maintaining security and cultural cohesion at home (Kong 2015).

In this new flourishing relationship with Hollywood companies, China has increased its know-how (Flew 2016), improved its domestic cultural industries, and started investing in film studios (Kokas 2017). Furthermore, the central control exerted on regulatory mechanisms of China's movie policy, in view of the decentralization and lack of control in the U.S. market - especially considering the growing Chinese investment in Hollywood (Shambaugh 2013; Thussu 2018) puts China in a position of power (Landreth et al. 2016; Kokas 2018). This is an unpredictable relationship (Kokas 2017), to be observed closely in both countries.

The Confucius Institutes, in turn, are some of the most prominent instruments of public diplomacy, as well as the most visible manifestation of China's cultural soft power agenda (Delisle 2010). According to its statute, ${ }^{3}$ CIs can be established in many different forms, with flexibility to attend to the needs of each country. The majority of CIs is a partnership between three entities: Hanban (CI's headquarters), a Chinese institution (usually a university) and a foreign institution

\footnotetext{
2 “Hollywood's dangerous obsession with China." 2016

3 "Constitution and By-Laws of the Confucius Institutes."
} 
(usually a university) (Gil 2017). With regard to resources, Hanban usually grants its partner universities subsidies of around US\$100-150 thousand to cover initial costs; after the institute is consolidated, financing comes from the joint efforts of Hanban and the partner university (Zhang and Gho 2018). Furthermore, Hanban might provide learning aids and send Chinese teachers. ${ }^{4}$

As for their function, CIs are focused on teaching the Chinese language and culture, providing cultural and educational exchange programs and strengthening ties with other nations, as well as promoting multiculturalism and building a more harmonious world. "Confucius classrooms" and "CI online" act similarly to CIs, but focus on middle and high school students (Switzer 2018). In general, criticism towards CIs is similar to that directed at other instruments of Chinese cultural diplomacy: they are supposedly controlled by the government, disseminating half-truths aimed to improve China's image abroad, and functioning as a mechanism of the Chinese Communist Party propaganda (Levine et al. 2014; Sahlins 2013; 2015). A special feature of the CIs is their presence in universities, which would represent a threat to academic freedom due to possible censorship to debates on sensitive topics for China.

Some criticism toward the CI, however, should be revisited and put into perspective. First, reproaching the use of CIs to meet China's strategic goals must take into consideration the fact that traditional European institutes, such as Alliance Française and the Goethe Institut also spread their countries' cultures and languages, which are openly stated in their mandates (Leung and Cros 2014; Liu 2017). Besides, the economic factor must be seen with caution, as case studies have shown that CIs are not the plentiful source of money that some claim. There is actually an increased tendency of financing by the foreign partners (Hartig 2015). Furthermore, Chinese control of CIs is not as intense as was once imagined, since local agents are responsible for most of the programming and activities. In addition, Chinese teachers are under the supervision of the host universities, and are evaluated by their students (Sweet 2017). However, financial dependency played an important role to some extent, which has contributed to a form of indirect control self-censorship - detected in many case studies (Kwan 2014; Hartig 2015).

Recent studies have analyzed how the establishment of CIs affected other countries' perception of China. According to Zhenjie Yuan, Junwanguo Guo and Hong Zhu (2016), with the exception of Africa and Oceania, the view on China deteriorated in the last decade, especially in Asia, Europe, and North America. While the CIs have been increasingly established on a global scale, China has failed to promote a positive image (Yuan et al. 2016).

The data series "The Soft Power 30,"6 elaborated by Portland, a strategic communication consultancy agency in London, in partnership with Center on Public Diplomacy (CPD) from the University of Southern California, and which has been published since 2015, ranks the 30 best soft power performers amongst countries in the world. China went from the $30^{\text {th }}$ position

\footnotetext{
${ }^{4}$ ibid.

5 ibid.

${ }^{6}$ USC Center of Public Diplomacy 2018
} 
in 2015 to $28^{\text {th }}$ in 2016, and reached the $25^{\text {th }}$ in 2017 . According to the report, China is still in constant ascent. This impressive three-position leap reflects the country's commitment to soft power in recent years. It must be highlighted, that the opening of hundreds of new CIs, combined with extensive international branding initiatives, strengthened the country's cultural offer. The publication emphasized that China's largest soft power resource is its culture. On the other hand, its largest weakness is the political issue, which combined with the human rights issue, is not compatible with the Western perspective, and tends to weaken global public opinion of China.

\section{Confucius Institutes in the United States: debates, perceptions and results}

The first CI opened its doors in November 2004 in Seoul, South Korea (Gil 2017). On the same month, the CI in the University of Maryland (UMD) was founded, starting operations in March 2005, becoming the second CI in the world. ${ }^{7}$ According to UMD's Office of China Affairs, the university has a long, deep relationship with China, dating back to 1915, when it received its first Chinese student, Chunjen Chen. ${ }^{8}$ The article entitled "The University of Maryland and China: A Shared History" stated that ever since then, UMD has been instrumental in the strengthening of U.S.-China relations, among others, through the promotion of Chinese culture and values in different academic fora in the 1940s, 50s and 60s, as well as hosting the famous matches of Ping Pong Diplomacy in 1972, in Cole Field House. This shared history with China paved the way for growing collaboration efforts between UMD and the Asian country through various actions, among other, the Maryland China Initiative (currently Office of China Affairs), and the Confucius Institute at the University of Maryland (CIM). ${ }^{9}$

From 2005 until today, the number of CIs in the U.S. has grown significantly: in April 2018, the U.S. hosted 110 CIs and 501 Confucius Classrooms, by far the country with the largest number of CIs $(21.3 \%)$ in the world. ${ }^{10}$ The reasons for this intense presence of CIs in the U.S. relates to the increased demand for Chinese language teaching. According to data from Modern Language Association (MLA), which monitors enrollment in foreign language classes in the U.S. since 1960, the number of students in Mandarin courses has increased by 90 -fold in the period between 1960 and 2013 (Sweet 2017). This growing interest impacted government actions, such as the National Security Language Initiative, ${ }^{11}$ launched in 2006 by then President George W. Bush, whose objective was to increase the number of American students learning

\footnotetext{
7 “Confucius Institute at the University of Maryland." 2015

8 "The University of Maryland and China: a shared history."

9 ibid.

10 "Over recent years, the Confucius Institutes development has been sharp"

11 “National Security Language Initiative." 2006
} 
“critical need foreign languages," 12 such as Arabic, Chinese, Russian, Hindi, Farsi and others, sponsored by already existing language programs, among them Chinese (Switzer 2018); the 100 Thousand Strong, launched by then President Barack Obama, who aimed to send 100 thousand U.S. students to study in China; and finally, after surpassing the goal, the 1 Million Strong, announced in 2015 by Barack Obama and Xi Jinping, aimed to expand the number of middle and high school students from the United States to study Mandarin to one million by $2020 .{ }^{13}$ In this sense, it becomes clear that learning Chinese is seen as politically relevant for the U.S., which means that the expansion of CIs in the country is complementary to these government initiatives (Sweet 2017; Switzer 2018).

In North American universities, a considerable part of CIs provides courses that count as extra credit. Many universities use CI teachers and resources to design their own Chinese language teaching program, or to turn existing programs into bachelor degrees (Sweet 2017; Hartig 2015).

The expansion of CIs in the U.S. has led to mistrust towards China's possible hidden intentions. There were suspicions that CIs aimed to project an official version of the country, which would serve as Chinese Communist Regime propaganda. Due to its presence in universities, it was even suggested that CIs represented a risk for academic freedom and freedom of expression.

One of the most severe criticisms came from Marshal Sahlins, an anthropologist and professor in the University of Chicago. In October 30, 2013, Sahlins published an article in The Nation accusing CIs of censuring political discussions and restricting the free exchange of ideas, questioning the reason why American universities maintained partnerships with these institutes. In June 2014,

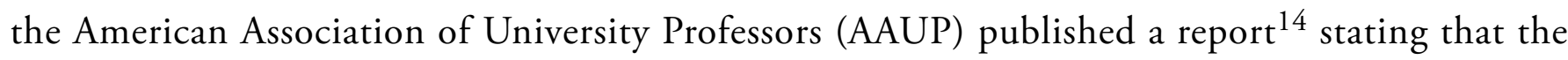
presence of CIs in campi was supposedly inconsistent with academic freedom and university autonomy. They thus recommended that all universities either terminate their engagements with CIs or renegotiate agreements with Hanban to ensure more autonomy.

In this environment of growing debate on CIs, a petition in the University of Chicago was launched demanding the contract with the local CI not being renewed, which should take place in 2014. The document counted with the signature of more than 100 academics, among others, the aforementioned professor Marshal Sahlins. That same year in September, Xu Lin, Hanban's Director-General, gave an interview to a Chinese newspaper, in which she mentioned, among other subjects, the petition in the University of Chicago. According to the article, $\mathrm{Xu}$ Lin supposedly told the university's administration that, if they wanted to terminate their contract with CI, she would concur. Still according to the article, this would have caused some anxiety to the administration, which agreed to renew the contract (Sweet 2017). Later, the University of Chicago published a statement declaring that the comments made by Hanban's director were incompatible with the

\footnotetext{
12 ibid.

13 "1 Million Strong."

14 “On partnerships with foreign governments: the case of Confucius Institutes.” 2014
} 
continuation of the partnership on equal conditions, thus terminating negotiations to renew the contract with the CI, which eventually closed. ${ }^{15}$

The CI in the University of Chicago had been closed for a week when the Institute in Pennsylvania State University was closed for different reasons. According to Sweet (2017), in Pennsylvania State University, the decision to close the CI was a more administrative issue, since its returns were not so positive. According to Eric Hayot (2014), former director of Pennsylvania State University's CI, one of his biggest frustrations was that the team at the university had ambitious ideas on how to use CI's resources - especially to support research not only in Humanities and Chinese culture, but also in science, politics, and the environment. This was regularly rejected by Hanban, which highlighted the CIs' cultural role. Furthermore, the CI did not provide much support to the already robust Chinese language program in the university, which did not make use of the teachers and teaching material sent by Hanban. Therefore, the work the CI could perform was restricted to few cultural activities inside and outside campus, such as performances by Chinese troupes and support to community events.

Notwithstanding the difference between the cases of the University of Chicago and of Pennsylvania, their simultaneity enhanced criticism of CIs, and exaggerated the cases' real meaning, as well as their potential effect on other CIs (Sweet 2017).

A document that sums up criticism of CIs in the U.S. is the National Association of Scholars' (NAS) report published in April 2017, which points out some worries regarding CIs: academic freedom - Chinese teachers, hired and paid by Hanban, were supposedly suffering pressure to avoid topics that were sensitive to China, and North American teachers were subjected to self-censorship; transparency - contracts between American universities and Hanban, as well as financial agreements and staff hiring policies, are rarely available to the public; free criticism - it was supposedly harder for universities with financial incentives to criticize Chinese policies, just to please China; and soft power - in order to avoid sensitive topics for China, CIs shaped an entire generation of students with selective knowledge of the country (Peterson 2017). The report makes many recommendations, among which the main and most incisive one is to close the CIs in all North American universities. While this did not occur, NAS suggested intermediary steps, especially those related to transparency and control on CIs. Finally, the report proposes that the U.S. Congress opens an investigation on CIs, in order to find out whether North American interests were being threatened by these institutions, as well as to evaluate the risks to national security (Peterson 2017).

In 2018, there came a new wave of criticism against CIs in the U.S. In early February, Republican Senator from Florida Marco Rubio wrote a letter to four universities in his state asking them to close down their CIs, since they were supposedly part of an aggressive Chinese campaign to repress the freedom of research and to subvert liberties ${ }^{16}$. Subsequently, the

\footnotetext{
15 "Statement on the Confucius Institute at the University of Chicago." 2014

16 "I write with regards to growing foreign influence operations of the People's Republic of China (PRC)..."
} 
University of West Florida stated it would not renew its contract with its CI, a decision that stemmed from the program's revision, as the university was not receiving adequate return for its students' interests. ${ }^{17}$

Still, in February 2018, FBI's director Christopher Wray, in a hearing at the United States Senate Select Committee on Intelligence, stated that North American academia was naïve regarding the risks that Chinese teachers and academics represented. He claimed that they took advantage of the open environment for research to collect information for the Chinese government and influence North American public opinion. He also stated that the FBI views not only the Chinese government, but all Chinese society as a threat; therefore, the case demands a response from the North American society as a whole. ${ }^{18}$

In March 2018, Texas Congressman Michael McCaul, a republican, and Henry Cuellar, a democrat, sent a bipartisan letter ${ }^{19}$ to all four Texan universities who hosted CIs, urging them to terminate their partnerships with these organizations, since they were threats to U.S. security, and served as a platform to collect information and promote China's political agenda. The letter stated that it was the citizens' responsibility to defend the values of freedom of expression and democracy in the U.S. In response to the congressmen's letter, in early April, Texas A\&M announced it would not renew its contract with the CI, as suggested. ${ }^{20}$

Still in March 2018, a bill was sent for debate in Congress which might have repercussions on CIs. The Foreign Influence Transparency Act of 2018 demanded the CIs and other entities that promote "foreign governments' political agenda" were registered as foreign agents (Allen-Ebrahimian et al. 2018). The bill would also compel universities to divulge donations from foreign entities that surpassed US\$ 50 thousand (currently, universities only divulge investments above US\$ 250 thousand and, as mentioned before, in most cases, Hanban invests between US\$ 100 thousand and US\$ 150 thousand in the CIs).

Many academics opposed this criticism. According to Edward A. McCord (2014), then director of Sigur Center for Asian Studies from The George Washington University, in Washington DC, the biggest problem with criticism towards CIs is that it often jumps from suspicion to conclusion, while repeating some anecdotal cases to support broader accusations that CIs might have a negative impact on academic life in the U.S. He claimed that, with more than 100 institutes, there is enough experience to evaluate how these organizations interact with North American academia and, considering that there are no reports of widespread problems and abuses, it seems these worries are unfounded.

Michael Hill, then director in the Center for Asian Studies in the University of South Carolina, has highlighted that the CI was indispensable for creating the courses, and added that he never witnessed any attempts of political interference in the university by the Institute (Levine et al.

\footnotetext{
17 “More scrutiny for Confucius Institutes; one to close." 2018

18 US Senate Select Committee on Inteligence 2018

${ }^{19}$ Congress of United States 2018

20 “Closing a Confucius Institute, at Congressmen's request." 2018
} 
2014). Stephen E. Hanson, professor in the College of William \& Mary, has stressed that, having participated as an administrator in two CIs (in William \& Mary and State of Washington), he never saw censorship or self-censorship: the Dalai Lama was on Campus at William \& Mary in 2013 without any manifestation from the CI; lectures on topics such as the 1989 Tiananmen Square protests, the status of Tibet and Taiwan, and the legitimacy of groups such as the Falun Gong were frequent on the campi where he worked - although they were never directly financed by Hanban (Levine et al. 2014).

The latest offensive against CIs catches the attention of some analysts, including the anthropologist Marshall Sahlins, a long time critic of CIs and one of the people who fostered the closing of the CI in the University of Chicago. According to Sahlins (2018): "In the incipient Cold War with China [...]," critical rhetoric against CIs migrated from academic freedom to espionage, and was captured by academics, universities, conservative politicians and state security agencies. Sahlins (2018) stated that North American government agencies now copy totalitarian actions of the Chinese government and dictate what can and cannot be taught in North American universities.

David Shambaugh (2018) has also questioned criticism towards CIs. He highlights that there is close involvement between the CI and The George Washington University where he teaches. He sees CIs as benign institutions devoted to the main mission of teaching the language and cultural studies, films, cooking, tai chi and other activities. According to Shambaugh (2018), there is no evidence that CIs are being politicized. There are, conversely, suppositions and insinuations based on few anecdotal cases. One of these suppositions is that CIs in some way influence how China is studied in U.S. campi, which is "absolutely wrong," since there is a complete firewall between the CIs, which teach language and culture, and the rest of the university and their curricula not only in the U.S., but all over the world. Therefore, CIs have no impact in Chinese studies, which is a misperception of journalists (Shambaugh 2018). However, the professor claims that it is indeed possible to improve transparency of CIs in campi, through more attentive supervision of contracts between them and their host universities in the U.S. He adds that one must be careful and pragmatic, especially when it comes to the media, which should act free of presumptions and insinuations.

A central point in Shambaugh's (2018) comments relates to how the U.S. media deals with CIs, which had been previously highlighted by other academics. In a 2014 study, Lueck, Pipps and Linan (2014) analyzed the New York Times' coverage of CIs, demonstrating that it is embedded in a context culturally charged with a politically constructed rhetoric. The CI was presented as an instrument of the Chinese government to actively influence North American perception of China's domestic policies and international actions. CI's contributions to enhance U.S. knowledge of Chinese language and culture were barely reported. Furthermore, when alluding to U.S. soft power, the term "soft power" was never mentioned. This eludes the idea of power of influence, unlike the constant mentioning of China's soft power. According to the authors, identifying CIs 
as a Chinese soft power response served to construct a stereotypical image of them to fit the dominant frame of the Communist Other in U.S. press (Lueck et al. 2014).

These narratives created by the media and politicians might have an impact on how CI students and their families interact with the institution. Jennifer Hubbert (2014) followed teachers, students and their parents in a Confucius Classroom in the U.S. for a year. She analyzed how parents and students regarded the Chinese State, the teachers and the CI's teaching material. According to her, it was possible to notice the continuity of a Cold War rhetoric that had been reshaped for a post-Cold War moment. Even if the teaching methods and learning material were meant to dispel the image of China as a threat to global well-being, they were received with predefined notions of China, which include human rights violations, authoritarianism, repression and citizens without free will. Hubbert (2014) highlights that because China is imagined as politically repressive and antagonistic to U.S. interests, the purposely apolitical nature of the teaching material and practices in class end up undermining Hanban's efforts to present an apolitical version of China. The apolitical nature of the material and the classes was seen as censorship by a dictatorial state.

However, Hubbert (2014) has stated that, despite Hanban's efforts to present an exclusively historical and apolitical content, the day to day affairs were not always predictable. When questioned on sensitive topics such as Tibet and Tiananmen, some teachers interacted with students and showed them their perspectives; and, in order to bypass sensitive issues and find common interest points with students, they focused on ordinary issues, such as visits to shopping malls. Interestingly, according to Hubbert (2014), when teachers acted outside the strict script defined by Hanban, students could identify with them and deconstruct their predefined notions of China. In other words, the less evident was the state's presence on their agents' actions, the more effective was soft power. Therefore, Hubbert (2014) argues that, in the case of CIs, actions of cultural soft power can become mechanisms to hide power, in order to increase it.

When it came to the script established by Hanban for CI teachers, Xin Liu (2017) points out that there are recommendations before they travel abroad. Xin Liu (2017) interviewed many CI teachers and, according to her, all of them said that in the Hanban-organized pre-departure training, they were instructed to respond with the official rhetoric or change the subject when politically sensitive discussions came up in the classroom. This was empirically confirmed by Hubbert (2014). However, as McCord (2014) has spoken of a "no-win situation" - in which it is expected of the CIs to promote events on Taiwan and Tibet to prove that they do not censure those topics, but if they present the Chinese Communist Party's perspective, it is seen as suspect propaganda -, Liu $(2017,153)$ also commented on this paradox. If CI teachers are accused of ignoring or avoiding these topics, will they be encouraged to enter the discussion and make China's voice be heard? She also adds: is it not contradictory to criticize censorship by censoring Chinese voices?

Liu (2017) references AAUP's definition of academic freedom, one of the institutions most critical to CI in the U.S.: "Teachers are entitled to freedom in the classroom in discussing their 
subject, but they should be careful not to introduce into their teaching controversial matter which has no relation to their subject." ${ }^{21}$ Liu (2017) argues that if the objective is teaching the Chinese language, politically sensitive issues could be regarded as "unrelated controversial topics." Therefore, based on AAUP's definition, these matters should not be dealt with in class. Therefore, Liu (2017) concludes that, if AAUP's definition of academic freedom is endorsed by more than 200 academic and teaching associations in the U.S., it is one more classic example of a double standard, since CI teachers who do the exact same thing are accused of interfering with academic freedom.

The case studies evoked in this section have shown many different perceptions of the larger or smaller presence of the Chinese state in CIs' operations. Overall, criticism to CIs in the early months of 2018, made amid tensions between China and the U.S. - which Sahlins (2018) calls, perhaps with some exaggeration, "an incipient Cold War" - makes the situation even more complicated. In this context, CIs might serve as ammunition for critics of China, but could also possibly strengthen ties between the two countries. To help mitigate this impasse, further research on the role played by cultural diplomacy in international relations might be essential.

\section{Conclusion}

The debate on the use of cultural diplomacy as an instrument of international insertion conforms to the increased value given to cultural soft power by the Chinese government in the $21^{\text {st }}$ Century. This has led to growing investments on instruments of Chinese cultural diplomacy (media, cinema, and CIs). The Chinese government has recognized the need to improve China's image in order to strengthen its presence worldwide. Cultural diplomacy was seen as a tool to disarm tensions and create a favorable environment for China's international insertion. It has been demonstrated that facing the difference between China's self-image and how the world perceives the country is the most important raison d'être in the effort to promote Chinese cultural soft power (Sun 2015).

In practice, China uses means of public and cultural diplomacy similar to other countries, such as the media, cinema, and cultural instruments. Notwithstanding, there are important particularities in China's conception of soft power and cultural diplomacy. The importance of the cultural dimension to the concept of soft power, as well as the broad definition of culture, justifies the use of the term cultural soft power in academic debates and Chinese political rhetoric. Furthermore, the Chinese state is prominent in the conduction of cultural diplomacy, whether in the command of government agencies that promote cultural diplomacy, or in choosing topics to be debated and disseminated. In turn, the idea of propaganda in China is closely related to the definition of public diplomacy, and the promotion of government actions abroad is free of

21 "1940 Statement of Principles on Academic Freedom and Tenure." 
negative meaning. Moreover, there is a double use of China's cultural diplomacy: besides spreading the Chinese culture abroad, the country aims at goals relating to cultural security and domestic social cohesion.

These particularities might not suffice to characterize a Chinese model of cultural diplomacy, but they make the analysis of China's cultural diplomacy actions more complex. Thus, even when they make use of traditional mechanisms of cultural diplomacy, China's actions are seen differently: the importance of the state is seen as a form of intervention and censorship; the prominence and broadness of the concept of culture is criticized as being ideological; Chinese public diplomacy is seen as propaganda; attempts to protect the country from a perceived cultural invasion are seen as arbitrary state actions that impede social manifestation.

Therefore, from an academic perspective, it has been argued that comprehending conceptual nuances and differences in approach might make the analysis of Chinese cultural diplomacy more objective and pragmatic. This is due to the fact that, as seen in the case study, the United States', perceptions of Chinese cultural diplomacy are still unclear and erratic. However, there is strong evidence that the Chinese government will continue to act so that Chinese stories are heard, their voices are disseminated, and their characteristics are well explained (Xi 2014).

\section{Acknowledgements}

This study was financed in part by the Conselho Nacional de Desenvolvimento Científico e Tecnológico - Brasil (CNPq) - Master scholarship.

\section{References}

“1 Million Strong.” US China Strong. http://100kstrong.org/initiatives/1-million-strong/ "1940 Statement of Principles on Academic Freedom and Tenure." Reports \& Publications. Washington, DC: American Association of University Professors. https://www.aaup.org/ report/1940-statement-principles-academic-freedom-and-tenure>

Allen-Ebrahimian, B., E. Groll, and R. Gramer. "New House bills take aim at foreign propaganda." Foreign Policy, March 20, 2018. http://foreignpolicy.com/2018/03/20/newhouse-bill-takes-aim-at-foreign-propaganda-russia-today-foreign-agent-manafort-fara/

Breslin, S. "A hard-bitten pursuit of soft power." In Bridging the trust divide: cultural diplomacy and fostering understanding between China and the West, edited by $\mathrm{H}$. Anheier and B. Lorentz. Berlin: Stiftung Mercator GmbH, 2012.

Cao, Q. "The language of soft power: mediating socio-political meanings in the Chinese media." Critical Arts: South-North Cultural and Media Studies, 25, no. 2 (2011): 7-24. doi: https://doi.org/10.1080/02560046.2011.552203 
“Closing a Confucius Institute, at Congressmen's request." Inside Higher Ed, April 9, 2018. https://www.insidehighered.com/news/2018/04/09/texas-am-cuts-ties-confuciusinstitutes-response-congressmens-concerns

"Confucius Institute at the University of Maryland." Hanban, 2015. http://english.hanban. org/node_8399.htm

"Constitution and By-Laws of the Confucius Institutes." Hanban. http://english.hanban.org/ node_7880.htm\#no4

Delisle, J. "Soft power in a hard place: China, Taiwan, cross-strait relations and US policy." Orbis 54, no. 4 (2010): 493-524. doi: https://doi.org/10.1016/j.orbis.2010.07.002

Ding, S. The dragon's hidden wings: how China rises with its soft power. Plymouth: Lexington Books, 2008.

Flew, T. “Entertainment media, cultural power, and post-globalization: the case of China's international media expansion and the discourse of soft power." Global Media and China 1, no. 4 (2016): 278-294. doi: https://doi.org/10.1177/2059436416662037

Gagliardone, I. "China as a persuader: CCTV Africa's first steps in the African mediasphere." Ecquid Novi: African Journalism Studies 34, no. 3 (2013): 25-40. doi: https://doi.org/10.1080/02560054.2013.834835

Gerring, J. "What is a case study and what is it good for?" American Political Science Review 98, no. 2 (2004): 341-354. doi: https://doi.org/10.1017/S0003055404001182

Gil, J. "China's cultural projection: a discussion of the Confucius Institutes." China: An International Journal 13, no. 1 (2015): 200-226.

Gil, J. Soft Power and the worldwide promotion of Chinese language learning: the Confucius Institute project. Bristol: Blue Ridge Summit, 2017.

Glaser, B. S., and M. E. Murphy. "Soft power with Chinese characteristics." In Chinese soft power and its implications for the United States: competition and cooperation in the developing world: a report of the CSIS smart power initiative, edited by C. McGiffert, 10-26. Washington, DC: CSIS, 2009.

Hartig, F. Chinese public diplomacy: the rise of the Confucius Institute. London: Routledge, 2015.

Hartig, F. "How China understands public diplomacy: the importance of national image for national interests." International Studies Review 18, no. 4 (2016): 655-680. doi: https://doi.org/10.1093/isr/viw007

Hartig, F. "China Daily: Beijing's global voice?” In China's media go global, edited by D. K. Thussu, H. Burgh, and A. Shi. London: Routledge, 2018.

Hayot, E. "Interview with Elizabeth Redden: another Confucius Institute to close." Inside Higher Ed, October 1, 2014. https://www.insidehighered.com/quicktakes/2014/10/01/ another-confucius-institute-close

“Hollywood's dangerous obsession with China." LA Times, October 07, 2016. http://www.latimes.com/opinion/op-ed/la-oe-daly-hollywood-20161007-snap-story.html 
$\mathrm{Hu}$, J. "Hold high the great banner of socialism with Chinese characteristics and strive for new victories in building a moderately prosperous society in all." Report to the Seventeenth National Congress of the Communist Party of China, August 15, 2007. http://www.china.org.cn/english/congress/229611.htm

$\mathrm{Hu}, \mathrm{Z}$., and D. Ji, "Ambiguities in communicating with the world: the 'Going-out' policy of China's media and its multilayered contexts." Chinese journal of communication 5, no. 1 (2012): 32-37. doi: https://doi.org/10.1080/17544750.2011.647741

$\mathrm{Hu}, \mathrm{Z}$., D. Ji, and Y. Gong. "From the outside in: CCTV going global in a new world communication order." In China's media go global, edited by D. K. Thussu, H. Burgh, and A. Shi. London: Routledge, 2018.

Hubbert, J. "Ambiguous states: Confucius Institutes and Chinese soft power in the US classroom.” PoLAR: Political and Legal Anthropology Review 37, no. 2 (2014): 329-349. doi: https://doi.org/10.1111/plar.12078

Hudson, V. M. Foreign policy analysis: classic and contemporary theory. 2. ed. Plymouth: Rowman \& Littlefield, 2014.

"I write with regards to growing foreign influence operations of the People's Republic of China (PRC)...” Marco Rubio US Senator for Florida. https://www.rubio.senate.gov/ public/_cache/files/34f01f9b-a642-4078-af7e-32536bfe7c25/7AA114B69F9469BFEBD4 7B5F71D65072.final-approved-letter-text-to-fl-universities.pdf

Johnson, J. B., H. T. Reynolds, and J. D. Mycoff. Political science research methods. 8. ed. Thousand Oaks: Sage, 2016.

Kokas, A. Hollywood made in China. Oakland: University of California Press, 2017.

Kokas, A. "Predicting volatility between China and Hollywood: using network management to understand Sino-US film collaboration." Global Media and Communication 14, no. 3 (2018). doi: https://doi.org/10.1177/1742766518759797

Kong, D. "Imaging China: China's cultural diplomacy through loan exhibitions to British museums." (thesis PhD in philosophy, School of Museum Studies University of Leicester, 2015).

Kwan, C. Y. W. "Cultural diplomacy and internationalization of higher education: the experience of three Confucius Institutes in Canada." Frontiers of Education in China 9, no. 1 (2014): 110-126.

Lai, H. "China's cultural diplomacy: going for soft power." In China's soft power and international relations, edited by L. Hongyi, and L. Yiyi, 83-103. London: Routledge Taylor \& Francis Group, 2012.

Landreth, J., S. Rosen, A. Kokas, and V. Ni. "Does Chinese investment pose a threat to Hollywood?" China File, January 13, 2016. http://www.chinafile.com/conversation/doeschinese-investment-pose-threat-hollywood

Leung, C.-C., and H. D. Cros. "Confucius institutes: multiple reactions and interactions." China: An International Journal 12, no. 2 (2014): 66-86. 
Levine, S., M. Mecacci, M. Hill, Z. Daojiong, S. E. Hanson, and M. Gallagher "The debate over Confucius Institutes in the United States.” Foreign Policy, July 11, 2014. http:// foreignpolicy.com/2014/07/11/the-debate-over-confucius-institutes-in-the-united-states/ Liu, X. “An alternative framework of analysis to investigate China's Confucius Institutes: a great leap outward with Chinese characteristics?" (Thesis PhD in philosophy, University of Central Lancashire, 2017).

Lueck, T. L., V. S. Pipps, and Y. Lin. "China's soft power: a New York Times introduction of the Confucius Institute." Howard Journal of Communications 25, no. 3, (2014): 324-349. doi: https://doi.org/10.1080/10646175.2014.925311

Congress of United States. "Confucius Institute Letter to Texas Colleges Universities and Other Educational Institutions”. Washington, DC, 2018. https://mccaul.house.gov/sites/mccaul. house.gov/files/Confucius\%20Institute\%20Letter\%20to\%20Texas\%20Colleges\%2C\%20 Universities\%2C\%20and\%20Other\%20Educational\%20Institutions.pdf

McCord, E. A. "Confucius Institutes: hardly a threat to academic freedoms." The Diplomat, March 27, 2014. https://thediplomat.com/2014/03/confucius-institutes-hardly-a-threatto-academic-freedoms/

"More scrutiny for Confucius Institutes: one to close." Inside Higher Ed, February 6, 2018. https://www.insidehighered.com/quicktakes/2018/02/06/more-scrutiny-confuciusinstitutes-one-close

"National security language initiative." U.S. Department of State Archive, 2006. https://2001-2009.state.gov/r/pa/prs/ps/2006/58733.htm

“On partnerships with foreign governments: the case of Confucius Institutes." Reports \& Publications. Washington, DC: American Association of University Professors, 2014. https://www.aaup.org/report/confucius-institutes

"Over recent years, the Confucius Institutes development has been sharp..." Confucius Institute/Classroom. http://english.hanban.org/node_10971.htm

Peterson, R. "Outsourced to China: Confucius Institutes and soft power in American higher education: a report by the National Association of Scholars." National Association of Scholars, April, 2017.

Price Waterhouse Cooper - PWC. Global entertainment \& media outlook 2017-2021. London: Price Waterhouse Cooper, 2017.

Rabinovitch, S. "The rise of an image-conscious China." China Security 4, no. 3 (2008): 32-46.

US Senate Select Committee on Inteligence. Reports. Washington, DC: US Senate, 2018. https://www.intelligence.senate.gov/hearings/open-hearing-worldwide-threats-hearing-1 Riva, N. F. "From soft power to "wenhuaruanshili": theory and practice in the Chinese discourse on soft power." (Thesis PhD in History, Institutions and International Relations in Modern and Contemporary Asia and Africa, Universitá degli Studi di Cagliari, 2016). 
Ross, R., and A. I. Johnston. "Introduction." In New directions in the study of China's foreign policy, edited by R. Ross and A. I. Johnston. Stanford: Stanford University Press, 2006. Sahlins, M. "China U." The Nation, October 30, 2013. https:/www.thenation.com/article/ china-u/

Sahlins, M. Confucius Institutes: academic malware. Chicago: Prickly Paradigm Press, 2015.

Sahlins, M. "Interview with Elizabeth Redden: Closing a Confucius Institute, at Congressmen's request." Inside Higher Ed, April 09, 2018. https://www. insidehighered.com/news/2018/04/09/texas-am-cuts-ties-confucius-institutes-responsecongressmens-concerns

Shambaugh, D. China goes global: the partial power. Oxford: Oxford University Press, 2013. Shambaugh, D. "China's soft-power push: the search for respect.” Foreign Affairs, July/ August, 2015. https://www.foreignaffairs.com/articles/china/2015-06-16/china-s-softpower-push

Shambaugh, D. The end of U.S. engagement with China? Debate in Brookings Institution, March 07, 2018. https://www.brookings.edu/wp-content/uploads/2018/03/ fp_20180307_us_china_transcript.pdf

Si, S. Expansion of international broadcasting: the growing global reach of China Central Television. Oxford: Reuter Institute, 2014.

"Statement on the Confucius Institute at the University of Chicago." UChicago News, September 25, 2014. https://news.uchicago.edu/article/2014/09/25/statement-confuciusinstitute-university-chicago

Sun, W. "Slow boat from China: public discourses behind the 'going global' media policy." International Journal of Cultural Policy 21, no. 4 (2015): 400-418.

Sweet, D. L. The art of winning hearts and minds: explaining divergent outcomes of Confucius Institutes in the US. (Thesis PhD in philosophy, Department of Political Science, George Mason University, 2017).

Switzer, A. The consequences of Confucius Institutes: understanding the opposition. (Dissertation Masters in Asian Studies, School of Arts and Sciences, Georgetown University, 2018).

“The Chinese are coming”, The Economist, March 04, 2010. https://www.economist.com/ node/ 15607496

“The University of Maryland and China: ashared history." Office of China Affairs. http://globalmaryland.umd.edu/offices/china/timeline

Thussu, D. K. "Globalization of the Chinese Media: the global context." In China's media go global, edited by D. K. Thussu, H. Burgh, and A. Shi. London: Routledge, 2018.

USC Center of Public Diplomacy - CPD. The Soft Power 30. Los Angeles: CPD, 2018. https://softpower30.com/

Wilkening, K. E. "Culture and Japanese citizen influence on the transboundary air pollution issue in northeast Asia." Political Psychology 20, no. 4 (1999): 701-723. doi: https://doi.org/10.1111/0162-895X.00165 
Xi, J. “China to promote cultural soft power." China Daily, January 1, 2014. http://usa.chinadaily.com.cn/china/2014-01/01/content_17208365.htm

Xiao, Y. "Confucius institutes in the US: platform of promoting China's soft power." Global Chinese 3, no. 1 (2017): 25-48.

Yang, S. X. "Soft power and the strategic context for China's 'media going global' policy." In China's media go global, edited by Daya Kishan Thussu, Hugo De Burgh and Anbin Shi. London: Routledge, 2018

Yanqiu, Z., and S. Matingwina. "Constructive journalism: a new journalistic paradigm of Chinese media in Africa." In China's media and soft power in Africa, edited by Z. Xiaoling, H. Wasserman, and W. Mano. New York: Palgrave Macmillan, 2016.

Yuan, Z., J. Guo, and H. Zhu. "Confucius Institutes and the limitations of China's global cultural network." China Information 30, no. 3 (2016): 334-356. doi: https://doi.org/10.1177/0920203X16672167

Zhang, G. Research outline for China's cultural soft power. Singapura: Springer, 2017.

Zhang, X., and Z. Guo. "The effectiveness of Chinese cultural centres in China's public diplomacy." In China's media go global, edited by D. K. Thussu, H. Burgh, and A. Shi. London: Routledge, 2018.

Zhou, Q., and Y. Wu. "The three patterns of Chinese International Communication.” In China's media go global, edited by D. K. Thussu, H. Burgh, and A. Shi. London: Routledge, 2018. 